\title{
Effects of sodium fluoride on water and acid secretion, soluble mucus and adherent mucus of the rat stomach
}

\author{
Kamel Gharzouli DEA PhD, Smain Amira Mphil, Seddik Khennouf Mphil, Akila Gharzouli DEA PhD
}

K Gharzouli, S Amira, S Khennouf, A Gharzouli. Effects of sodium fluoride on water and acid secretion, soluble mucus and adherent mucus of the rat stomach. Can J Gastroenterol 2000;14(6):493-498. Chronic and acute ingestion of fluoride may lead to both structural and functional alterations of the gastric mucosa. The aim of this study was to investigate the effects of sodium fluoride on gastric secretion and mucosal barrier. Filling the rat stomach for $1 \mathrm{~h}$ with sodium fluoride ( 5 and $20 \mathrm{mmol} / \mathrm{L}$ ) induced an increase in fluid, fucose and galactose output. This effect was accompanied by a marked $\mathrm{pH}$-dependent reduction of titratable acidity of the lumen. The amount of Alcian blue bound to adherent mucus was reduced in a $\mathrm{pH}$-independent manner by sodium fluoride. The absence of a correlation between soluble glycoproteins and adherent mucus suggests that sodium fluoride does not stimulate mucus secretion, but rather acts as a barrier-breaking agent by its accumulation, together with acid, into the mucosa.

Key Words: Acid secretion; Adherent mucus; Fluoride; Soluble mucus; Stomach
Effet du fluorure de sodium sur la sécrétion d'eau et d'acide ainsi que sur le mucus soluble et adhérent de l'estomac du rat

RÉSUMÉ : L'ingestion chronique ou aiguë de fluorure pourrait entraîner des modifications structurales et fonctionnelles de la muqueuse gastrique. La présente étude avait pour objectif d'étudier l'effet du fluorure de sodium sur la sécrétion gastrique et la barrière muqueuse. Le remplissage de l'estomac d'un rat pendant une heure avec du fluorure de sodium ( 5 et $20 \mathrm{mmol} /$ ) a entraîné une augmentation de la production de liquide, de fructose et de galactose. Cet effet s'accompagnait d'une réduction significative dépendante du $\mathrm{pH}$ de l'acidité titrable de la lumière de l'estomac. La quantité de bleu alcian lié aux mucus adhérent était réduite de façon indépendante du $\mathrm{pH}$ par le fluorure de sodium. L'absence de corrélation entre les glycoprotéines solubles et le mucus adhérent permet de croire que le fluorure de sodium ne stimule pas la sécrétion de mucus mais joue plutôt le rôle de briseur de barrière en s'accumulant de concert avec l'acide, dans la muqueuse.
$\mathrm{I}_{\mathrm{s}}^{\mathrm{n}}$ $\mathrm{n}$ addition to its widely accepted cariostatic effect and its possible preventive or therapeutic roles in osteoporosis $(1,2)$, fluoride is harmful when taken acutely in large doses or chronically in moderate doses. Among the soft tissues, the stomach is exposed to the highest concentrations of fluoride when dental products, in concentrations of 12 to $640 \mathrm{mmol} / \mathrm{L}$, are inadvertently swallowed, or during osteoporosis treatment (50 $\mathrm{mg}$ fluoride/day) (2).

Mucosal injury, ranging from erythema to mucosal erosions, of the upper gastrointestinal tract was observed in patients undergoing fluoride therapy (otosclerosis) or presenting with skeletal fluorosis as a result of high levels of fluoride in drinking water (greater than $1 \mathrm{mg} / \mathrm{L}$ ) (3). Localized hemorrhagic areas of the gastric mucosa are visible after ingestion of a single dose of sodium fluoride $20 \mathrm{mg}(53 \mathrm{mmol} / \mathrm{L})$ by healthy volunteers (4). Rat gastric mucosa injury, induced by a single dose of sodium fluoride 10 or $50 \mathrm{mmol} / \mathrm{L}$ in hydrochloric acid $100 \mathrm{mmol} / \mathrm{L}$, is observed microscopically within 10 mins and continues to develop for the next hour (5).

Besides its damaging effects on gastric mucosa, fluoride was shown to inhibit basal and histamine-stimulated acid secretion, but increase water secretion in the cat and rat stomach $(6-8)$. By using the chambered dog gastric wall as a model, it has been shown that sodium fluoride induces a net

Department of Animal Biology, Institute of Biology, Ferhat Abbas University, Setif, Algeria

Correspondence and reprints: Dr Kamel Gharzouli, Département de Biologie Animale, Institut de Biologie, Université Ferhat Abbas, 19000 Setif, Algeria. Telephone +213-5-85-49-30, fax +213-5-85-22-13

Received for publication June 30, 1998. Accepted February 23, 1999 
secretion of water, sodium, potassium and mucus accompanied by a marked loss of acid from the luminal side (9). In addition, perfusion of rat stomach with sodium fluoride $(\mathrm{pH}$ 3.2) led to a net decrease of transmural electrical potential difference (10).

Fluoride is rapidly absorbed by the stomach as hydrofluoric acid (11). The fractional absorption is inversely related to the luminal $\mathrm{pH}$ and, therefore, to the concentration of hydrofluoric acid (12). The injurious effects of fluoride may result from acid accumulation in the interstitial fluid, and inhibition of a variety of enzymes (13) and membrane transport systems by ionic fluoride (14).

The present study examined the combined effects of sodium fluoride and luminal $\mathrm{pH}$ on water and acid output, and soluble and adherent mucus. To evaluate both kinds of mucus, fucose and galactose were used to represent the soluble fraction and mucus-bound Alcian blue to represent adherent mucus.

\section{ANIMALS AND METHODS}

Female Wistar rats, weighing between 200 and $250 \mathrm{~g}$, were deprived of food for $48 \mathrm{~h}$. They were allowed free access to water until $1 \mathrm{~h}$ before the experiment. During the fasting period, the animals were kept individually in cages with widemesh wire bottoms to prevent coprophagy. The animals were then anesthetized by an intraperitoneal injection of urethane $(1.2 \mathrm{~g} / \mathrm{kg})$. The stomach was ligated at the level of the cardia and filled, through the pylorus, with a precisely measured volume $(1 \mathrm{~mL})$ of the test solution and immediately closed with a pyloric ligation, with care being taken to avoid main vessel supplies. The abdomen was sutured, and the animal was kept under a heating lamp. One hour later, the stomach was rapidly removed and freed from its mesenteric attachments. The stomach content was drained and completely recovered by washing with $10 \mathrm{~mL}$ isotonic saline. The recovered solution was weighed and centrifuged at $1300 \mathrm{~g}$ for 10 mins at room temperature to remove contaminating debris. Samples with more than $0.5 \mathrm{~mL}$ of sediment were discarded. Supernatants were used for acid and glycoprotein determinations. The stomach was then blotted dry, weighed and submitted to adherent mucus determination.

Experimental design: To test the effect of fluoride and acidity, animals were randomly divided into six groups $(n=8$ to 11). Rat stomachs were filled with one of the following test solutions: isotonic saline (sodium chloride $150 \mathrm{mmol} / \mathrm{L}$ ); sodium fluoride $5 \mathrm{mmol} / \mathrm{L}$; sodium fluoride $20 \mathrm{mmol} / \mathrm{L}$; hydrochloric acid $50 \mathrm{mmol} / \mathrm{L}$; sodium fluoride $5 \mathrm{mmol} / \mathrm{L}$ in hydrochloric acid $50 \mathrm{mmol} / \mathrm{L}$; sodium fluoride $20 \mathrm{mmol} / \mathrm{L}$ in hydrochloric acid $50 \mathrm{mmol} / \mathrm{L}$. All of these test solutions were made isotonic by the addition of the appropriate amount of sodium chloride. The isotonic saline and sodium fluoride $50 \mathrm{mmol} / \mathrm{L}$ solutions served as control conditions.

Adherent gastric mucus measurement: The amount of mucus adhering to the gastric wall was measured using Alcian blue dye according to the method described by Corne et al (15). This cationic dye binds to glycoproteins and soluble mucopolysaccharides to insoluble complexes without pene- trating mucosal cells. The stomach was opened along the greater curvature, and the glandular portion was excised, immersed for $2 \mathrm{~h}$ in $0.1 \%$ Alcian blue and dissolved in sucrose $0.16 \mathrm{~mol} / \mathrm{L}$ buffered with sodium acetate $0.05 \mathrm{~mol} / \mathrm{L}$ ( $\mathrm{pH}$ adjusted to 5.8 with hydrochloric acid). The unbound dye was removed by two subsequent washings of 15 and 45 mins in sucrose $0.25 \mathrm{~mol} / \mathrm{L}$. The mucus-bound dye was eluted by tissue immersion for $2 \mathrm{~h}$ in magnesium chloride $0.5 \mathrm{~mol} / \mathrm{L}$. The resulting solution was shaken briefly with an equal volume of diethyl ether to dissolve particles that may interfere with the spectrophotometric determination. The optical density of the aqueous phase was then measured at $605 \mathrm{~nm}$ and converted to micrograms of Alcian blue per gram of wet glandular tissue by comparison with a standard curve obtained from dilution of $0.1 \%$ Alcian blue.

Glycoprotein determination: Glycoprotein concentration of the gastric content was estimated by galactose and fucose determination. Glycoprotein separation from the luminal washings was carried out by ethanol precipitation (16). Absolute ethanol $(15 \mathrm{~mL})$ was added to $5 \mathrm{~mL}$ of the supernatant obtained from the luminal content. The resulting suspension was kept overnight at $4^{\circ} \mathrm{C}$ for complete precipitation, after which the precipitate was collected by centrifugation ( $8700 \mathrm{~g}$ for 30 mins at $4^{\circ} \mathrm{C}$ ). The pellet was washed with ethanol $(5 \mathrm{~mL})$ and submitted to a second centrifugation. The final pellet was then dissolved in $10 \mathrm{mmol} / \mathrm{L}$ sodium hydroxide $(10 \mathrm{~mL})$. Galactose and fucose concentrations were determined according to the phenol-sulphuric acid method (17) and to the technique described by Dische and Shettles (18), respectively. Galactose and fucose contents were expressed in $\mu g / g$ wet tissue.

Fluid and acid determination: Fluid output (mL/g of wet tissue) was determined by subtracting the recovered volume from that of the filling solution. Acid was determined by titration of $0.5 \mathrm{~mL}$ of the sample with sodium hydroxide $10 \mathrm{mmol} / \mathrm{L}$ to $\mathrm{pH} 7$ (Metrohm Titrator, Herisau, Switzerland). Acid output ( $\mu \mathrm{Eq} / \mathrm{g}$ wet tissue) was calculated as the difference between the total recovered amount and that of the filling solution; negative values indicate a loss from the lumen.

Statistical analysis: Data are expressed as means \pm SEM. The statistical significance of differences was determined by one-way ANOVA followed by Dunnett's multiple test. The level of significance was fixed at 5\%. Correlations were determined by the least squares method.

\section{RESULTS}

Fluid output: Filling the stomach with hydrochloric acid $50 \mathrm{mmol} / \mathrm{L}$ had no effect on fluid output compared with isotonic saline $(\mathrm{P}>0.05)$. The pooled fluid output was $0.184 \pm 0.047 \mathrm{~mL} / \mathrm{g}(\mathrm{n}=18)$. However, the luminal fluid was increased by $280 \%$ and $340 \%$ compared with controls when the stomach was exposed to sodium fluoride 5 and $20 \mathrm{mmol} / \mathrm{L}$, respectively $(\mathrm{P}<0.05)$ (Figure 1$)$. Sodium fluoride, at both concentrations, in acidified medium $(50 \mathrm{mmol} / \mathrm{L}$ hydrochloric acid) also resulted in a significant increase of $380 \%$ and $256 \%$, respectively $(\mathrm{P}<0.05)$ (Figure 1 ). 


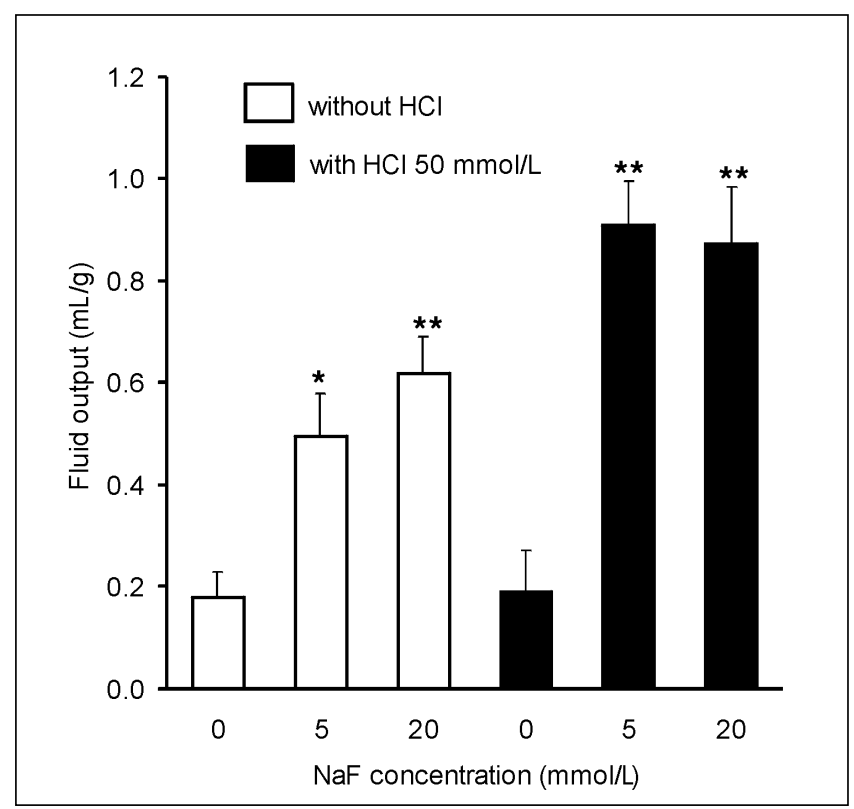

Figure 1) Effect of sodium fluoride on fluid output ( $\mathrm{mL} / \mathrm{g}$ of wet tissue) in the rat stomach. The stomach was filled, for $1 \mathrm{~h}$, with sodium fluoride in acid-free or acidic isotonic solutions. Data are means \pm SEM. Comparisons are made with the respective control condition (without sodium fluoride). $* P<0.05 ; * * P<0.001$

Acid output: Acid output was dependent on both medium $\mathrm{pH}$ and sodium fluoride concentration in the lumen (Figure 2). At low concentration of sodium fluoride $(5 \mathrm{mmol} / \mathrm{L})$, acid output did not change significantly with respect to controls, whereas sodium fluoride $20 \mathrm{mmol} / \mathrm{L}$ induced a net reduction of titratable acidity from the lumen $(\mathrm{P}<0.05)$. The combination of sodium fluoride, at both concentrations, with hydrochloric acid caused a marked reduction of titratable acidity in the gastric lumen $(\mathrm{P}<0.05)$. The observed increase of acid loss ranged from $65 \%$ to $82 \%$.

Sugar output: Under control conditions, the total recovered amounts of galactose and fucose were $124 \pm 22 \mu \mathrm{g} / \mathrm{g}(\mathrm{n}=8)$ and $32.8 \pm 1.9 \mu \mathrm{g} / \mathrm{g}(\mathrm{n}=8)$, respectively. Stomach exposure to hydrochloric acid $50 \mathrm{mmol} / \mathrm{L}$ had no significant effect on galactose and fucose contents. However, sodium fluoride ( 5 or $20 \mathrm{mmol} / \mathrm{L}$ ) in the presence or absence of hydrochloric acid induced a net increase of galactose and fucose in the luminal fluid (Figures 3,4). Galactose output variation induced by sodium fluoride in acidic medium increased from $60 \%$ to $119.7 \%$ when the concentration was brought from 5 to $20 \mathrm{mmol} / \mathrm{L}$. In contrast, fucose output increase was less pronounced (from $40.2 \%$ to $69.8 \%$ ). Similar variations were also observed in acid-free medium and indicate that the effect of sodium fluoride was $\mathrm{pH}$-independent. A high correlation was observed between galactose and fucose contents whether the luminal fluid was rendered acidic or not $(\mathrm{P}<0.001$; Table 1$)$. The ratio of fucose to galactose was not changed by sodium fluoride and/or hydrochloric acid (Table 1). The pooled mean ratio was $0.291 \pm 0.029(n=50)$.

Alcian blue recovery: Stomach treatment with hydrochloric acid $50 \mathrm{mmol} / \mathrm{L}$ did not alter the amount of mucus-bound Alcian blue (Figure 5). The pooled value was $156.0 \pm 9.5 \mu \mathrm{g} / \mathrm{g}$

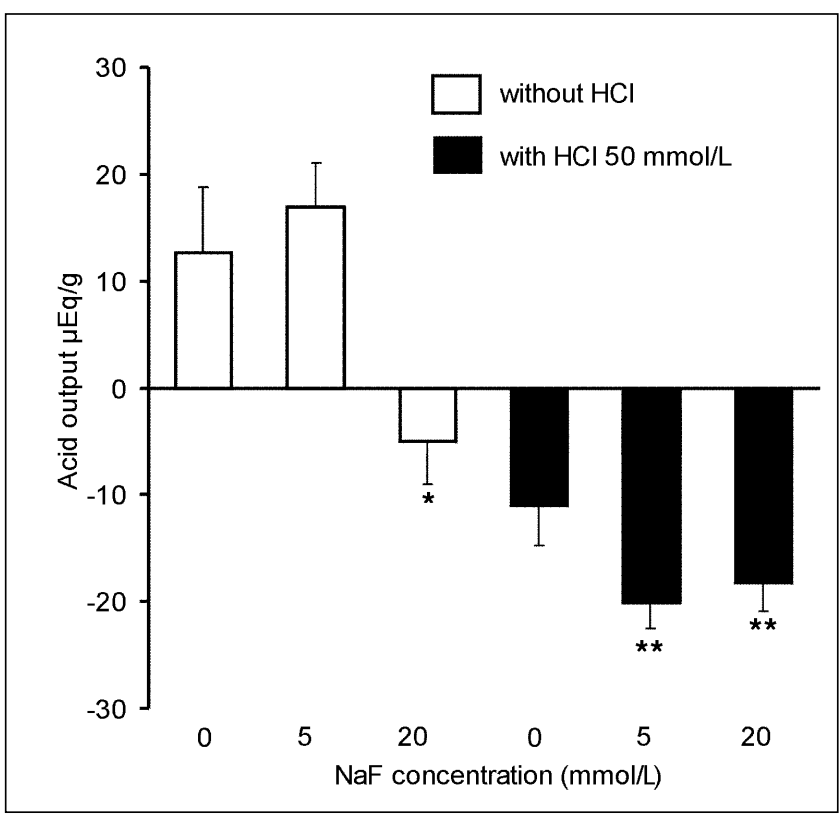

Figure 2) Effect of sodium fluoride on acid output ( $\mu$ Eq/g of wet tissue) in the rat stomach. The stomach was filled, for $1 \mathrm{~h}$, with sodium fluoride in acid-free or acidic isotonic solutions. Negative values indicate a reduction of titratable acidity of the lumen. Data are means \pm SEM. Comparisons are made with the respective control condition (without sodium fluoride). $* P<0.05 ; * * P<0.01$

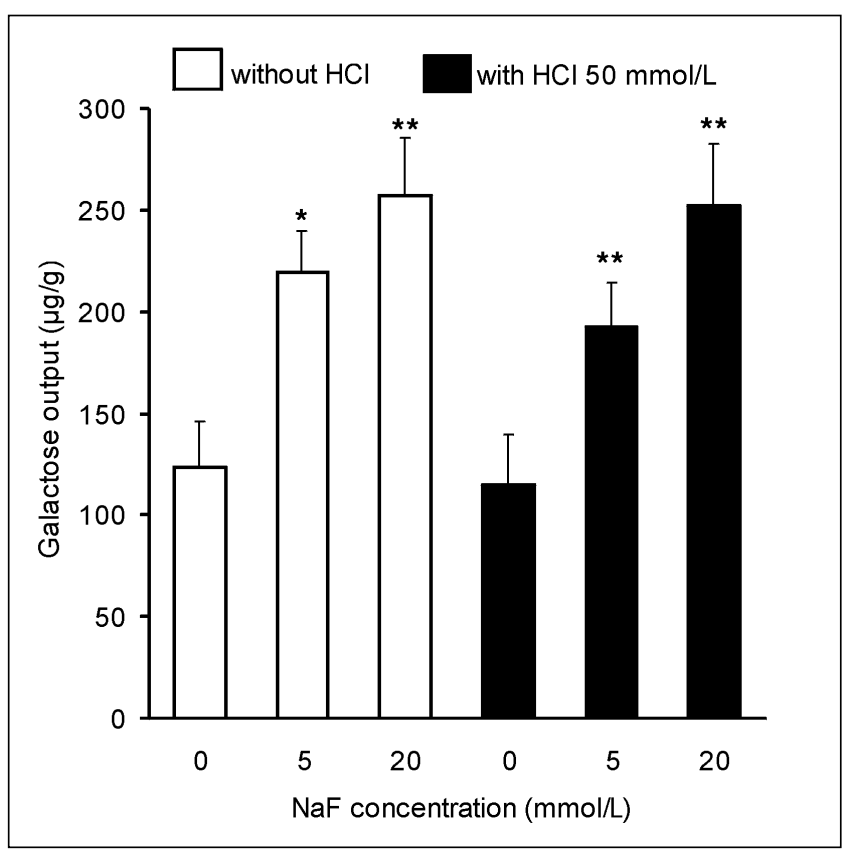

Figure 3) Effect of sodium fluoride on galactose output ( $\mu \mathrm{g} / \mathrm{g}$ of wet tissue) in the rat stomach. The stomach was filled, for $1 \mathrm{~h}$, with sodium fluoride in acid-free or acidic isotonic solutions. Data are means \pm SEM. Comparisons are made with the respective control condition (without sodium fluoride). $* P<0.01 ; * * P<0.001$

$(n=18)$. Both concentrations of sodium fluoride reduced the recovered dye. This effect was independent on both luminal $\mathrm{pH}$ and sodium fluoride concentration (Figure 5). Despite that sodium fluoride induced a decrease of bound-dye parallel to an increase of galactose and fucose in the lumen, there 


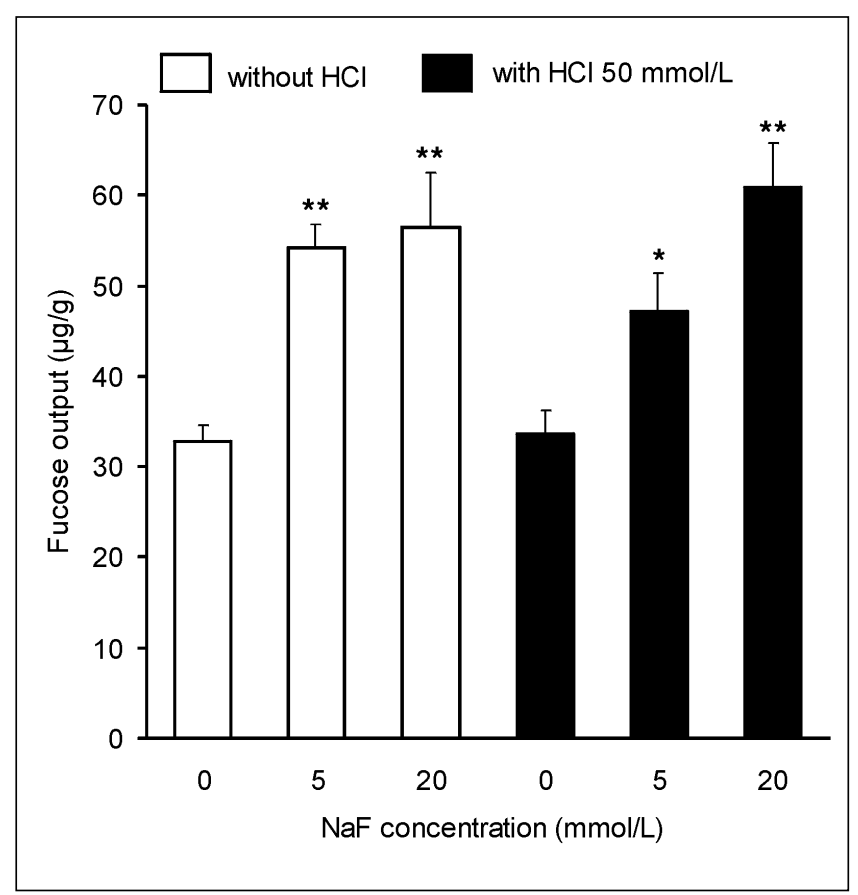

Figure 4) Effect of sodium fluoride on fucose output ( $\mu \mathrm{g} / g$ of wet tissue) in the rat stomach. The stomach was filled, for $1 \mathrm{~h}$, with sodium fluoride in acid-free or acidic isotonic solutions. Data are means \pm SEM. Comparisons are made with the respective control condition (without sodium fluoride). $* P<0.05 ; * * P<0.01$

was no significant correlation between these two parameters (Table 1).

\section{DISCUSSION}

The results indicate that sodium fluoride 5 and $20 \mathrm{mmol} / \mathrm{L}$ in combination with hydrochloric acid $50 \mathrm{mmol} / \mathrm{L}$ induced a net increase of fluid output accompanied by a reduction of titratable acidity present in the lumen of the rat stomach. It has been shown that an intermediate concentration of sodium fluoride $(10 \mathrm{mmol} / \mathrm{L})$ was able to reduce basal and histamine-stimulated acid secretion and to induce a loss of acid after filling the stomach with hydrochloric acid $100 \mathrm{mmol} / \mathrm{L}$ (6). In normal saline, sodium fluoride $5 \mathrm{mmol} / \mathrm{L}$ did not affect acid output. Thus, it appears that the effect of sodium fluoride depends on luminal $\mathrm{pH}$. In the ex vivo dog

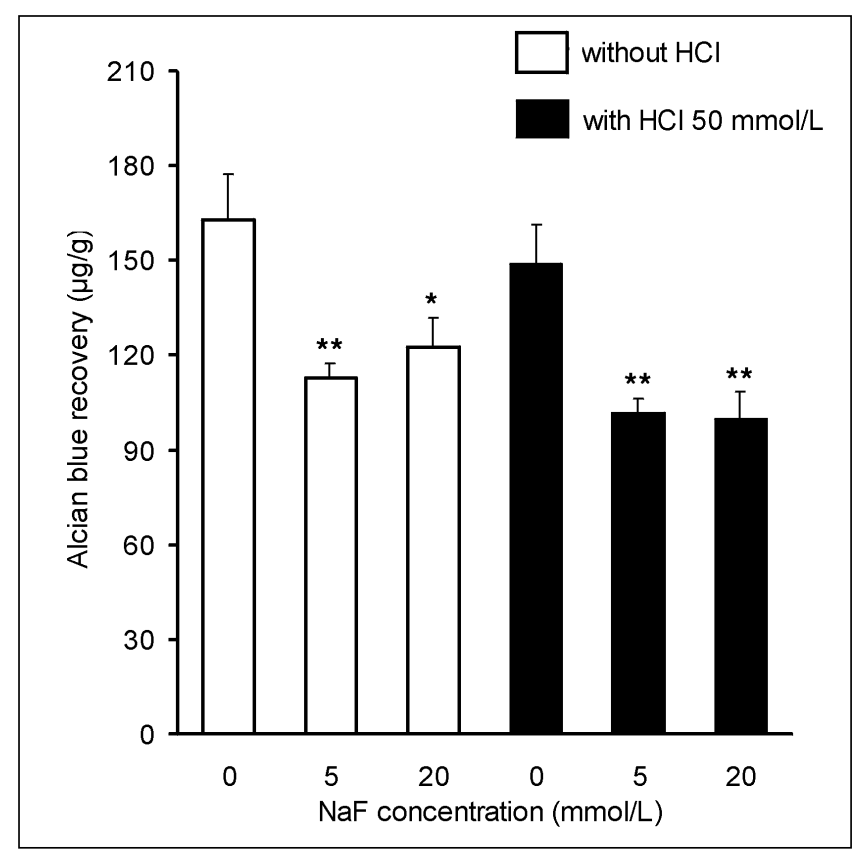

Figure 5) Effect of sodium fluoride on Alcian blue ( $\mu \mathrm{g} / \mathrm{g}$ of wet tissue) bound to rat gastric mucosa. The stomach was filled, for $1 \mathrm{~h}$, with sodium fluoride in acid-free or acidic isotonic solutions. Data are means \pm SEM. Comparisons are made with the respective control condition (without sodium fluoride). $* P<0.01 ; * * P<0.001$

stomach, the threshold concentration of fluoride able to induce a net loss of acid is close to $1 \mathrm{mmol} / \mathrm{L}$ but in the presence of hydrochloric acid is $149 \mathrm{mmol} / \mathrm{L}$ (19). Concentrations of sodium fluoride above $5 \mathrm{mmol} / \mathrm{L}$ in hydrochloric acid $50 \mathrm{mmol} / \mathrm{L}$ (the present study) and $10 \mathrm{mmol} / \mathrm{L}$ in hydrochloric acid $140 \mathrm{mmol} / \mathrm{L}$ (19) had no further effect on acid output. The role of luminal acidity is to reduce the threshold concentration of fluoride by the formation of a greater amount of hydrofluoric acid molecules. An increase of water output has already been reported in rat (6) and dog (19). This was accompanied by an increase of sodium and potassium $(8,19)$.

Numerous data have accumulated to show that the rate of fluoride absorption by the stomach is rapid and inversely related to the $\mathrm{pH}$ of the luminal content $(6,12)$. Fluoride is

TABLE 1

Correlation between the different components in the gastric secretion and Alcian blue recovery after filling a rat stomach with acid-free or acidic sodium fluoride solutions

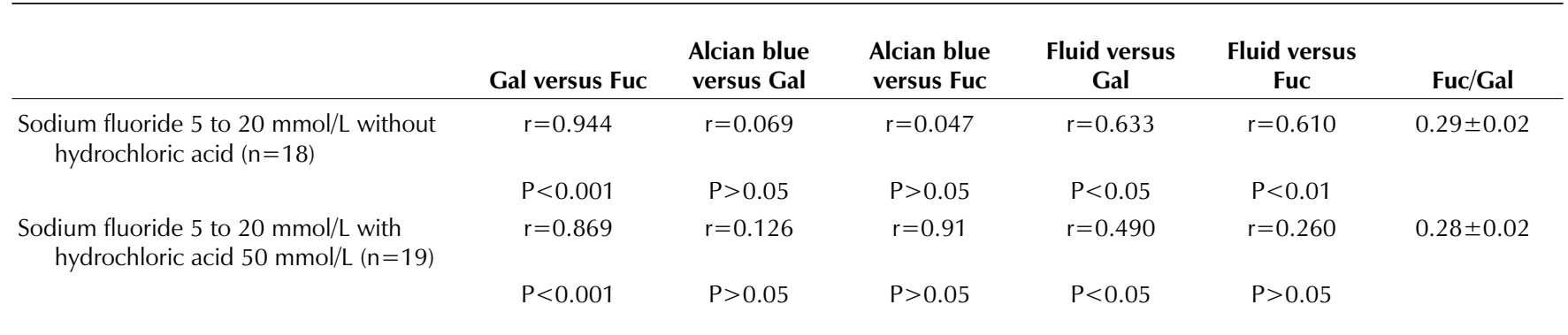

Fuc Fucose; Gal Galactose 
thought to be passively absorbed by the epithelia in the hydrofluoric acid form (11). Fluoride with a pK 3.4 forms hydrofluoric acid easily when present in acidic medium. Therefore, when the stomach is exposed to fluoride, the concentration of hydrofluoric acid increases and establishes a chemical gradient. Hydrofluoric acid molecules are highly diffusible (20) and enter the mucosa rapidly, where they dissociate into ionic fluoride and hydrogen. The increase of water, sodium and potassium secretion may result from the damaging effect of accumulated fluoride and acid into the mucosa. The effects of fluoride on the stomach resemble those of acetylsalicylic acid ( $\mathrm{pK} 3.6$ ), which causes gross mucosal damage and increases mucosal ultrafiltration (21) as a result of cytotoxic concentrations of drug anions in the mucosa (22). Gross mucosal damage induced by fluoride has been reported with elevated concentrations of fluoride and acidity. They range from intense redness of the corpus mucosa to localized hemorrhagic areas $(4,9,23)$. Inspection of stomachs after treatment with sodium fluoride with or without hydrochloric acid did not reveal any consistent damage pattern, apart from redness of the corpus, which is frequently observed with sodium fluoride $20 \mathrm{mmol} / \mathrm{L}$ plus hydrochloric acid $50 \mathrm{mmol} / \mathrm{L}$. The decrease in stomach blood flow induced by sodium fluoride $(8,23)$ accounts for the redness of the stomach observed after exposure to sodium fluoride. It has been shown that the treatment of cultured porcine endothelial cells with sodium fluoride results in increased formation of endothelium-derived relaxing factor (24). The vascular stasis resulting from endothelial smooth muscle relaxation may delay the disposal of excessive intramucosal acid from the mucosa and lead to gastric damage.

Estimation of luminal mucus in gastric washings has been used extensively as an index of secretion. For example, pentagastrin, histamine and prostaglandins have been reported to increase luminal glycoproteins (25-29). However, various phenomena may induce variation in soluble mucus - a shift of adherent glycoproteins to soluble mucus, an increased rate of mucus secretion of adherent glycoproteins or an increased breakdown of mucus by excessive mucolytic activity of pepsin. The extent of adherent mucus (gel thickness, dye bound to mucus) must be determined to distinguish between true secretion and degradation of mucus. Both ethanolprecipitable glycoproteins in the gastric washings and bound Alcian blue were applied in this study. The validity of the ethanol precipitation method to determine mucin content of the gastric juice has been demonstrated by comparison with the gel filtration method (30).

Galactose and fucose output were increased by sodium fluoride stomach treatment ( 5 and $20 \mathrm{mmol} / \mathrm{L}$ ) in a concentration-dependent manner only in acidic medium. In acid-free or acidic medium, the ratio of fucose to galactose was unchanged by sodium fluoride and hydrochloric acid treatments. The correlation observed between fucose and galactose in gastric fluid supports the view that both belong to the same glycoprotein molecules and suggests that sodium fluoride does not affect the composition of secreted mucus. Furthermore, galactose and fucose output were correlated to fluid volume in the lumen, except for fucose under acidic conditions. One may ask whether the increased mucus secretion was due to a washing out of soluble glycoproteins from the gel accompanying an increased output of fluid originating from the mucosa. The amount of recovered Alcian blue bound to adherent mucus was reduced by sodium fluoride in normal and acidic saline. A similar effect has been reported for the chambered dog stomach, which showed a moderate to severely decreased periodic acid Schiff staining after application of sodium fluoride in acidic medium (19). The observed increase of galactose and fucose is unlikely to reflect increased mucus secretion because there was no obvious correlation with Alcian blue recovery. This conclusion may be supported by the fact that oral administration of hydrochloric acid $350 \mathrm{mmol} / \mathrm{L}$, used as a mild irritant, caused a significant increase of mucin in the mucus gel and a decrease in the deep mucosa (31). Komuro et al (31) suggested that acid stimulates mucus secretion from mucus neck cells of the deep corpus mucosa.

\section{CONCLUSIONS}

Fluoride acts as a barrier-breaking agent, inducing ultrafiltration of fluid from the interstitium into the gastric lumen accompanied by an increased acid back-diffusion, an outpouring of glycoproteins and a reduction of adherent mucus. The rapid penetration of fluoride in the mucosa as hydrofluoric acid molecules may play an amplifying role where once fluoride has induced local vascular stasis, intramucosal acidity increases and ultimately leads to a pronounced mucosal damage. Results of the present study suggest that patients under prolonged fluoride therapy may suffer from gastric damage if luminal acidity is not lowered with inhibitors or neutralized with antacids.

ACKNOWLEDGEMENTS: The present study was supported by grants (F1901/04/95) from the Ministère de l'Enseignement Supérieur et de la Recherche Scientifique and the Agence Nationale pour le Développement de la Recherche en Santé, Algeria. The International Foundation for Science (Stockholm, Sweden) is also acknowledged for its support to Kamel Gharzouli (F/2564-1).

\section{REFERENCES}

1. Cerklewski FL. Fluoride availability - Nutritional and clinical aspects. Nutr Res 1997;5:907-29.

2. Pak CYC, Sakhaee K, Adamshuet B, Piziak V, Peterson RD, Poindexter JR. Treatment of postmenopausal osteoporosis with slowrelease sodium fluoride. Ann Intern Med 1995;123:401-8.

3. Susheela AK, Das TK, Gupta IP, et al. Fluoride ingestion and its correlation with gastrointestinal discomfort: Fluoride 1992;25:5-22.

4. Spak CJ, Sjostedt S, Eleborg L, Veress B, Perbeck L, Ekstrand J. Tissue response of gastric mucosa after ingestion of fluoride. Br Med J 1989;298:1686-7.

5. Easmann RP, Pashley DH, Birdsong NL, McKinney RV, Whitford GM. Recovery of rat gastric mucosa following single fluoride dosing. J Oral Pathol 1985;14:779-92.

6. Gharzouli K, Senator A, Gharzouli A, Mustapha M, Abed S. Acid secretion and fluoride absorption by the ligated stomach of the rat: Mutual influences of fluoride and luminal acidity. Fluoride 1995;28:3-9. 
7. Bond AM, Hunt JN. The effect of sodium fluoride on the output of some electrolytes from the gastric mucosa of cats. J Physiol 1956;133:317-29.

8. Reed JD, Smy JR. The effects of sodium fluoride on gastric acid and electrolyte output in the anaesthetized cat. J Physiol 1980;301:39-48.

9. Birdsong-Whitford NL, Whitford GM, Pashley DH, El Moslemany I. Fluoride-induced changes in canine gastric mucosal ion fluxes. J Dent Res 1987;66:341. (Abst 1879)

10. Gharzouli K, Gharzouli A, Aiouaz L, Berais A. Effect of sodium fluoride on the transmural potential difference of the rat stomach. Fluoride 1996;29:13-9.

11. Whitford GM. Acute fluoride toxicity. In: Myers HM, ed. The Metabolism and Toxicity of Fluoride, 2nd edn. Basel: Karger, 1996:112-36.

12. Whitford GM, Pashley DH. Fluoride absorption: The influence of gastric acidity. Calcif Tissue Int 1984;36:302-7.

13. Rastogi R, Upreti RK, Kidwai AM. Effect of fluoride on the intestinal epithelial cell brush border membrane. Bull Environ Contam Toxicol 1987;39:162-7.

14. Hawkins C, Xu A, Narayanan N. Comparison of the effect of fluoride on the calcium pumps of cardiac and fast skeletal muscle sarcoplasmic reticulum: Evidence for tissue-specific qualitative difference in calcium-induced pump conformation. Biochim Biophys Acta 1994;1191:231-43.

15. Corne SJ, Mirrissey SM, Woods RJ. A method for the quantitative estimation of gastric barrier mucus. J Physiol 1974;242:166P-7P

16. Murakami N, Fujisaki H, Oketani K, Wakabayashi T. Effect of secretin on stress-induced gastric bleeding in rats. Dig Dis Sci 1985;30:346-52.

17. Dubois M, Gilles KA, Hamilton JK, Rebers PA, Smith F. Colorimetric method for determination of sugars and related substances. Anal Chem 1958;28:350-6.

18. Dische Z, Shettles LB. A specific colour reaction of methylpentoses and a spectrophotometric micromethod for their determination. J Biol Chem 1948;175:596-603.

19. Birdsong-Whitford NL, Whitford GM, Pashley DH, El Moslemany I.
Effect of fluoride on canine gastric mucosal ion fluxes. J Dent Res 1989;68:335. (Abst 1229)

20. Gutknecht J, Walter A. Hydrofluoric and nitric acid transport through lipid bilayer membranes. Biochim Biophys Acta 1981;644:153-6.

21. Davenport HW. Salicylate damage to the gastric mucosal barrier. N Engl J Med 1967;276:1307-12.

22. Garner A. Mechanisms of action of aspirin on the gastric mucosa of the guinea pig. Acta Physiol Scand Suppl 1978;454:101-10.

23. Fujii A, Tamura T. Deleterious effects of sodium fluoride on gastrointestinal tract. Gen Pharmacol 1989;20:705-10.

24. Graier WF, Schmidt K, Kukovetz WR. Effect of sodium fluoride on cytosolic free $\mathrm{Ca}^{2+}$-concentrations and cGMP-levels in endothelial cells. Cell Signal 1990;2:369-75.

25. Vagne M, Fargier MC. Effect of pentagastrin and secretin on gastric mucus secretion in conscious cats. Gastroenterology 1973;65:757-63.

26. Vagne M, Perret G. Effect of duodenal acidification on gastric mucus and acid secretion in conscious cats. Digestion 1976;14:332-41.

27. Bolton JP, Palmer D, Cohen MM. Stimulation of mucus and nonparietal cell secretion by $\mathrm{E}_{2}$ prostaglandins. Am J Dig Dis 1978;23:359-64.

28. Johansson C, Kollberg B. Stimulation by intragastrically administered $\mathrm{E}_{2}$ prostaglandins of human gastric mucus output. J Clin Invest 1979;9:229-32.

29. Pasquier MC, Vatier J, Poitevin C, Vallot T, Mignon M. Assessment of mucus glycoprotein erosion by measurement of sialic acid in gastric secretions: Pathophysiologic and therapeutic aspects. J Clin Gastroenterol 1991;13(Suppl 1):S22-31.

30. Azumi Y, Ichikawa T, Ishihara K, Hotta K. The validity of the ethanol precipitation method for the measurement of mucin content in human gastric juices and its possible relationship to gastroduodenal diseases. Clin Chim Acta 1993;221:219-25.

31. Komuro Y, Ishihara K, Ishii K, et al. A separating method for quantifying mucus glycoprotein localized in the different layer of rat gastric mucosa. Gastroenterol Jpn 1992;27:466-72. 


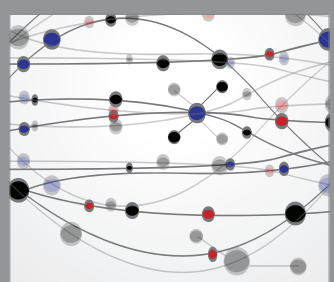

The Scientific World Journal
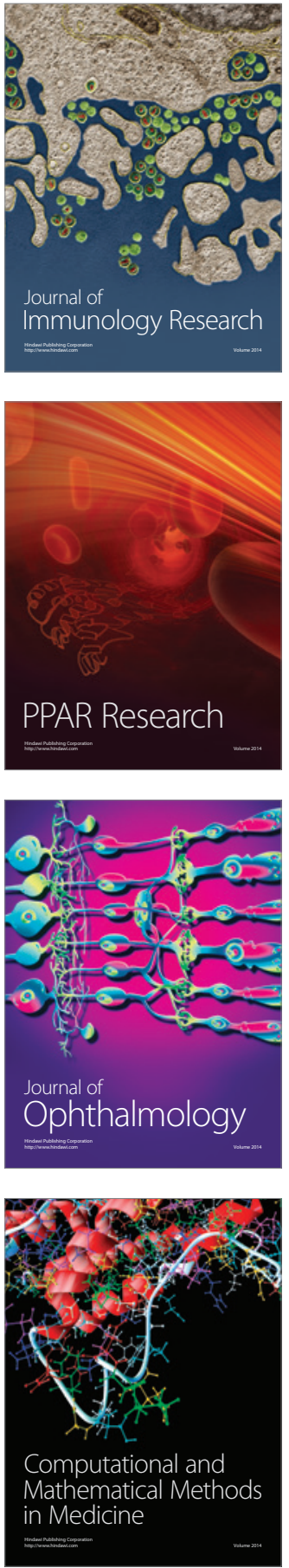

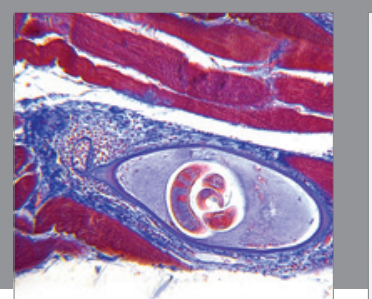

Gastroenterology Research and Practice

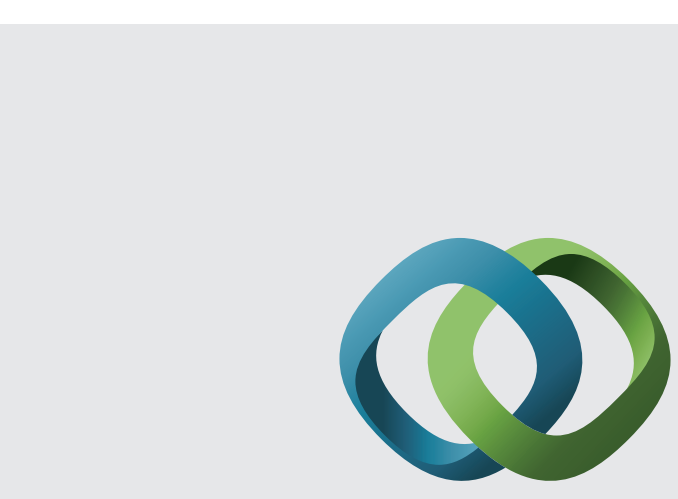

\section{Hindawi}

Submit your manuscripts at

http://www.hindawi.com
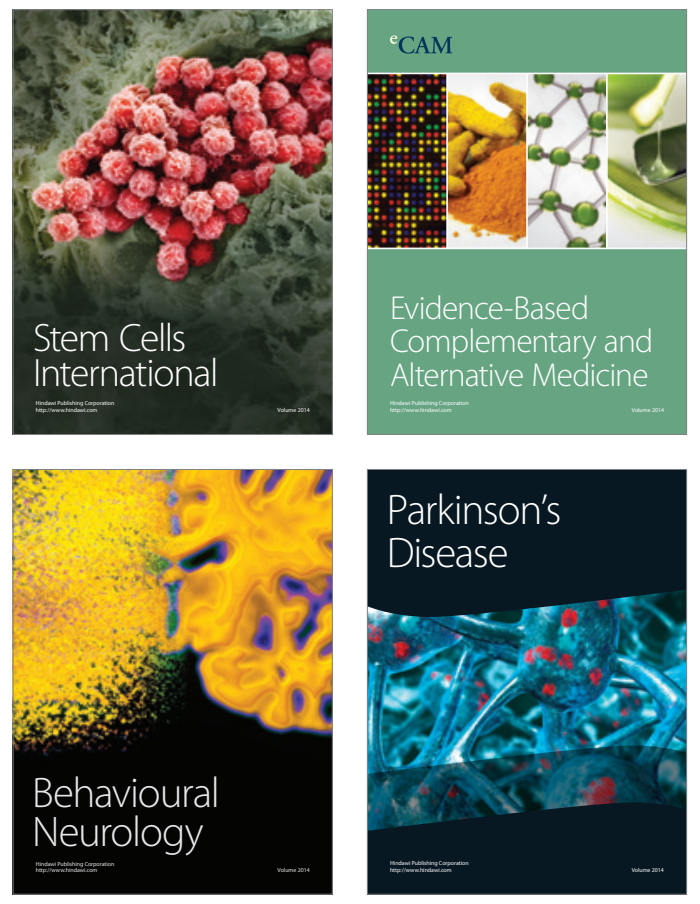
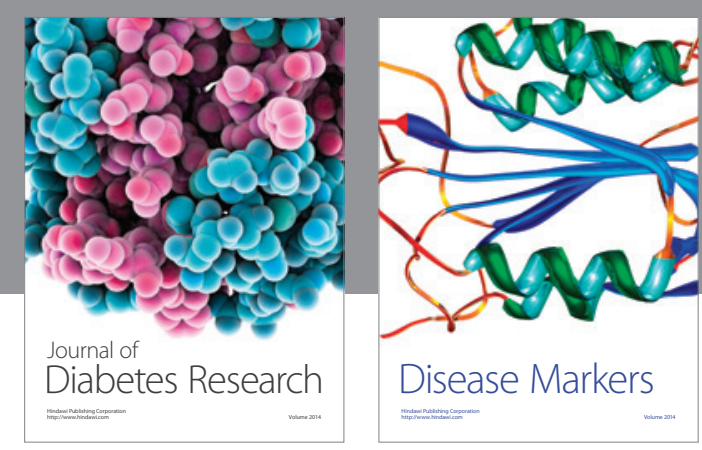

Disease Markers
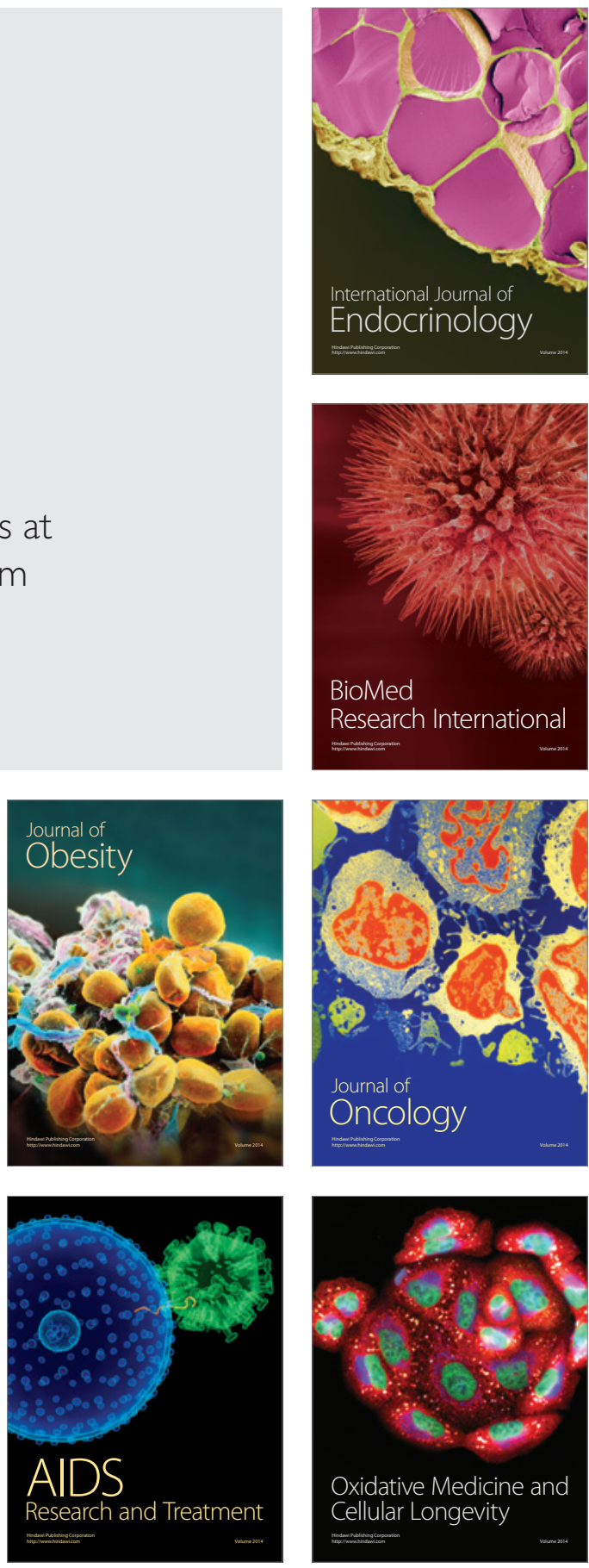